\title{
Serras e pantanais arenosos: solos e geoambientes em unidade de conservação da Amazônia, Brasil
}

\author{
Highlands and sandy wetlands: soils and \\ geoenvironments of a conservation unit \\ in Amazonia, Brazil
}

Carlos Ernesto Gonçalves Reynaud Schaefer ${ }^{1}$, Prímula Viana Campos², Hugo Galvão Candido ${ }^{1}$, Guilherme Resende Corrêa ${ }^{3}$, Raiza Moniz Faria ${ }^{1}$, José Frutuoso do Vale Jr ${ }^{4}$

1 Departamento de Solos, Universidade Federal de Viçosa. Av. P.H. Rolfs, s/n, Centro, 36570-900, Viçosa, Minas Gerais, Brasil

2 Departamento de Biologia Vegetal, Universidade Federal de Viçosa. Av. P.H. Rolfs, s/n, Centro, 36570-900, Viçosa, Minas Gerais, Brasil

3 Instituto de Geografia, Universidade Federal de Uberlândia, Campus Santa Mônica. Av. João Naves de Ávila, 2121, 38400-902, Uberlândia, Minas Gerais, Brasil

4 Departamento de Solos e Engenharia Agrícola, Universidade Federal de Roraima. BR 174, Km 12, 69301970, Monte Cristo, Boa Vista, Roraima, Brasil

Corresponding author: Carlos Ernesto Gonçalves Reynaud Schaefer (carlos.schaefer@ufv.br)

Academic editor: A. M. Leal-Zanchet | Received 16 July 2019 | Accepted 9 December 2019 | Published 6 February 2020

Citation: Schaefer CEGR, Campos PV, Candido HG, Corrêa GR, Faria RM, Vale Jr JF (2020) Serras e pantanais arenosos: solos e geoambientes em unidade de conservação da Amazônia, Brasil. Neotropical Biology and Conservation 15(1): 43-69. https://doi.org/10.3897/neotropical.15.e49221

\section{Resumo}

Unidades de conservação representam a principal estratégia para a preservação e recuperação de recursos naturais brasileiros. Para nortear o seu planejamento e gestão, informações relativas aos geoambientes constituem um referencial integrado indispensável. O objetivo deste estudo foi descrever os aspectos pedológicos associados à identificação, caracterização e mapeamento de geoambientes do Parque Nacional Serra da Mocidade, Roraima, norte do Brasil, de forma a subsidiar o manejo ecológico da unidade. Para a estratificação geoambiental foram avaliados os aspectos pedológicos, geomorfológicos e vegetação. Foram descritos e coletados 19 perfis de solos. A caracterização da vegetação 
foi realizada in loco. Foram descritos quatro pedoambientes, com destaque para os seguintes solos: Espodossolo Humilúvico, Espodossolo Ferri-Humilúvico, Espodossolo Ferrilúvico, Neossolo Quartzarênico, Neossolo Regolítico, Neossolo Flúvico, Plintossolo Háplico, Plintossolo Argilúvico, Gleissolo Melânico e Cambissolo Háplico. Foram identificadas 12 unidades geoambientais. No Parque, destacase um contraste entre serras e morrarias da zona florestada e os grandes espaços inundáveis e baixios do pediplano Rio Branco-Rio Negro. Além disso, essa área de conservação possui o mais antigo e, provavelmente, o mais importante conjunto montanhoso granítico-gnáissico do norte amazônico, de grande extensão e topografia complexa. Este estudo evidencia a singularidade de cada geoambiente, subsidiando na definição mais precisa e adequada das formas de manejo do Parque.

\begin{abstract}
Conservation units represent the main strategy for the preservation and recovery of Brazilian natural resources. In order to guide their planning and management, information on geoenvironments is a key integrated reference. The aim of this study was to describe the pedological aspects associated with the identification, characterization and mapping of geoenvironments of the Serra da Mocidade National Park, Roraima, northern Brazil, in order to subsidize the ecological management of the unit. For the geoenvironmental stratification, pedological, geomorphological and vegetation were assessed and, 19 soil profiles were described and collected. The characterization of the vegetation was carried out in loco. Four pedoenvironments were described, with emphasis on the following soils: Podzols, Arenosols, Regosols, Fluvisols, Plinthosols, Acrisols, Gleysols and Cambisols. Twelve geoenvironmental units were identified. In the Park, there is a contrast between mountain ranges and gentle rolling hills of the forested zone and the extensive, ill-drained floodplains of the Rio Branco-Rio Negro pediplain. In addition, the conservation unit contains the only ancient granite-gneiss hilly plateau of North Amazonia, of large extension and complex topography. This study shows the uniqueness of each geoenvironment, subsidizing a more precise and adequate management practices of this Park.
\end{abstract}

\title{
Palavras-chave
}

Parque Nacional Serra da Mocidade, relação solo-vegetação, pedoambiente

\section{Keywords}

Serra da Mocidade National Park, soil-vegetation relationship, pedoenvironment

\section{Introdução}

As regiões tropicais apresentam expressiva diversidade de paisagens e, consequentemente, caracterizam-se biologicamente mais diversas que outras zonas climáticas (Hawkins et al. 2003). O Brasil é considerado um dos maiores detentores de biodiversidade mundial, tanto em número de espécies quanto em níveis de endemismo (Giulietti et al. 2005; Joly et al. 2011). Contudo, muitas espécies, comunidades e ecossistemas associados estão sob constante ameaça, sobretudo pela ação antrópica, com a crescente destruição de habitats naturais (Pitman e Jorgensen 2002).

No país, as unidades de conservação (UCs) representam a principal estratégia oficial para a preservação e recuperação de vários atributos inerentes aos recursos naturais, como biodiversidade, qualidade ambiental, paisagem natural e funções ecológicas (Paz et al. 2006; Fonseca et al. 2010). Atualmente, a região amazônica é detentora 
da maior extensão de área protegida (Mello e Artaxo 2017), enquanto outra parcela significativa da sua cobertura vegetal tem sido dizimada sob impactos de queimadas, extração madeireira, garimpo e expansão da fronteira agrícola (Santos et al. 2017).

Além da exploração dos recursos naturais, as UCs enfrentam vários problemas, como a regularização fundiária, falta de infraestrutura e recursos humanos e financeiros, além da ausência de um plano de manejo para nortear as ações dos gestores (Fonseca et al. 2010; Gamba e Ribeiro 2017). A carência de informações sobre o meio biótico, abiótico e social impede a elaboração do plano de manejo de forma coerente e eficiente (Rodrigues et al. 2015). As UCs apresentam unidades geoambientais, que abrigam ecossistemas e comunidades diversas. Os geoambientes correspondem ao ambiente geográfico cuja extensão territorial exibe certa homogeneidade com relação aos atributos ambientais, como: substrato geológico, relevo, solo, drenagem, clima e cobertura vegetal (Dias et al. 2002; Brandão et al. 2010). Constituem um referencial integrado a ser levado em consideração no processo de planejamento e monitoramento dos recursos naturais das UCs do país (Mendonça et al. 2013; Rodrigues et al. 2015), uma vez que sua proteção resulta na conservação de ambientes e preservação de espécies que, muitas vezes, ainda não são conhecidas.

O Parque Nacional (PARNA) Serra da Mocidade faz parte do grande mosaico de UCs do norte amazônico, sob gestão do ICMBio (Instituto Chico Mendes de Conservação da Biodiversidade) no arco de terras elevadas que abrange os Parques Nacionais do Monte Roraima até o Pico da Neblina (ICMBio 2018). Do ponto de vista da conservação, a região constitui um ecossistema local de suportes ecológicos singulares (Ab'Saber 2002), de grande relevância para a manutenção da biodiversidade. Contudo, o conhecimento sobre o meio biótico e abiótico, norteadores de uma gestão ambiental efetiva da UC, ainda é incipiente.

Neste contexto, visto que o PARNA Serra da Mocidade não possui informações relativas ao meio físico em escalas adequadas ao seu planejamento e monitoramento, este trabalho teve como objetivos contribuir com um estudo detalhado dos aspectos pedológicos e geomorfológicos de suas áreas mais representativas, bem como identificar, caracterizar e mapear as unidades geoambientais que compõem as paisagens do setor principal (leste) do Parque Nacional Serra da Mocidade, de forma a ampliar o conhecimento da região amazônica e gerar subsídios à elaboração do plano de manejo do Parque.

\section{Material e métodos}

\section{Área de estudo}

O trabalho foi realizado no setor leste do Parque Nacional (PARNA) Serra da Mocidade, unidade de conservação criada no ano de 1998 (ICMBio 2018) (Fig. 1). O Parque localizase na região centro-sul do Estado de Roraima, no município de Caracaraí, na região norte do Brasil, com área de 376.812,61 hectares, entre as coordenadas $1^{\circ} 00^{\prime} 47.67 \mathrm{~N}$, $62^{\circ} 34^{\prime} 49^{\prime \prime} \mathrm{W}$ e $1^{\circ} 25^{\prime} 36.25^{\prime \prime N}, 61^{\circ} 36^{\prime} 45.89^{\prime \prime W}$ (ICMBio 2018). Segundo a classificação de 


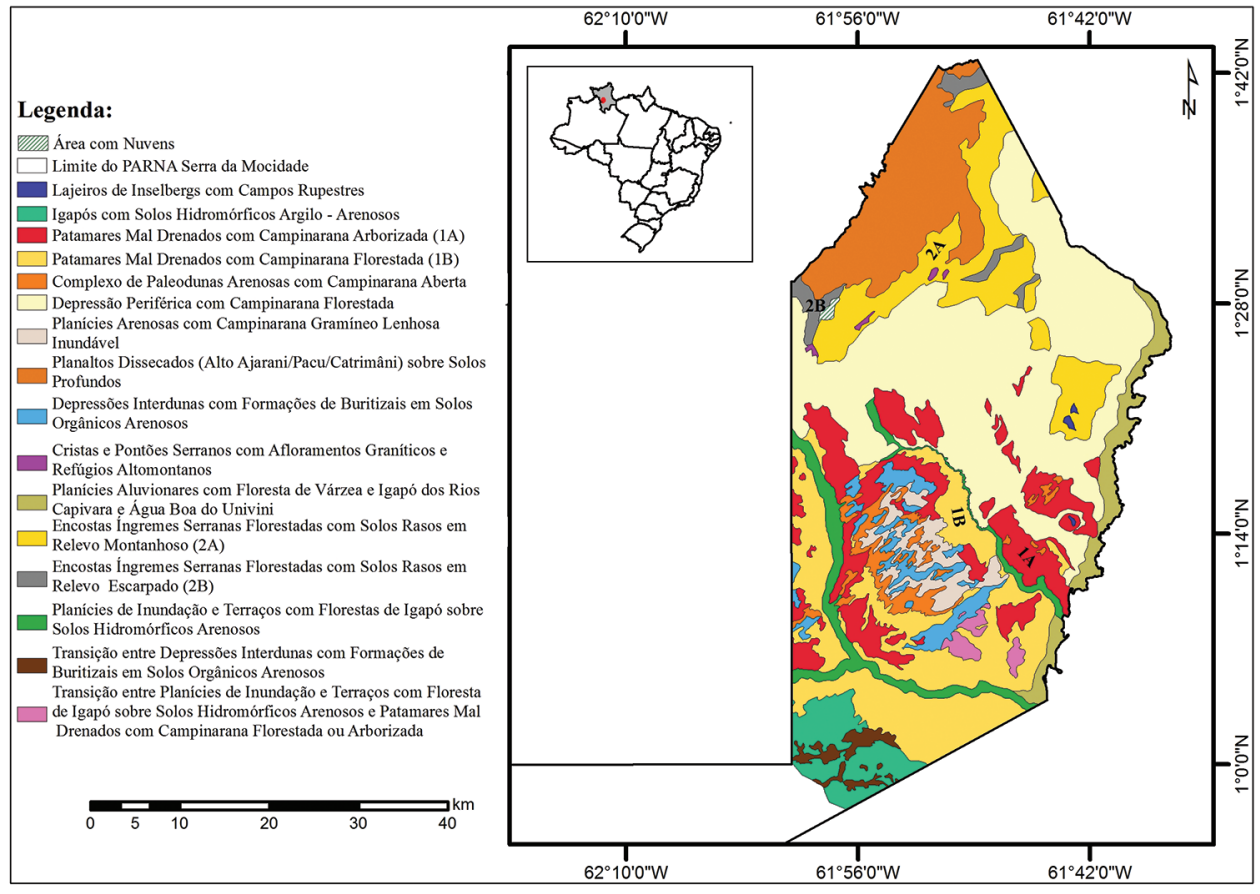

Figura 1. Geoambientes do Parque Nacional Serra da Mocidade, norte do Brasil.

Köppen (1948), o clima predominante na região é o Amw' (chuva do tipo monção), com estação seca curta e acentuada, coincidente com o outono. A precipitação média anual é de $1.794 \mathrm{~mm}$ (Agência Nacional de Águas 2009). Com temperatura média anual é de $26^{\circ} \mathrm{C}$. Entretanto, variações altitudinais impõem regimes climáticos sob influência orográfica, com subclimas de floresta nebular, subtropicais nas porções mais elevadas do Parque, além de zonas xerófitas nos paredões e lajeiros de rocha granítica exposta.

O PARNA Serra da Mocidade corresponde a parte do domínio tectonoestratigráfico da Guiana Central (Reis et al. 2003), com dois setores geologicamente distintos: o domínio da Depressão Sedimentar do Baixo Rio Branco (depósitos aluvionares do Quaternário) nas partes baixas ( 45 a $330 \mathrm{~m}$ de altitude), em relevo plano e levemente abaciado, com Latossolos, Plintossolos, Gleissolos, Espodossolos, e Neossolos Flúvicos e Quartzarênicos; e as serras e pontões (até aproximadamente $1.900 \mathrm{~m}$ de altitude) de natureza Granítico-Gnáissica, que formam um conjunto montanhoso único do norte Amazônico, com orientação NE/SW e solos do tipo Latossolos, Cambissolos e Neossolos Litólicos.

A unidade de conservação se destaca pela relevância hidrológica, com condição de área montanhosa, bem drenada, e área de imensa depressão inundável, do baixo rio Branco-rio Negro, recoberta por sedimentos arenosos (Formação Içá) (CPRM 2000). A malha hídrica apresenta peculiaridades, com rios de "águas negras", ácidas, devido à matéria orgânica em suspensão; "águas brancas", barrentas, carregadas de sedimentos; e os "águas mistas", mescla dos dois (ICMBio 2018). As áreas rebaixadas são condicionadas pela moldura fluvial imposta por quatro importantes rios: Branco (leste), 
Capivara (centro), Catrimâni (oeste) e Água Boa do Univini (centro). Os dois últimos apresentam características fluviais meandrantes em sua planície aluvionar, emolduram os Pantanais de areias brancas, e dificultam, pela natureza pouco permeável das camadas argilosas, a drenagem em direção ao rio Branco. Na área serrana, destaca-se as capturas de drenagens do rio Ajarani ao rio Branco. Além disso, Igarapés de águas claras ou negras drenam canais bem retilíneos no setor do pediplano arenoso.

As coberturas arenosas holocênicas com retrabalhamento eólico dominam a planície sedimentar denominada de Pantanal Setentrional (Santos e Nelson 1995; CPRM 2000). Essas coberturas constituem campos de dunas parabólicas e longitudinais, alongadas paralelamente conforme os ventos dominantes (NE), com vegetação herbáceo-arbustiva, característica de Campinas e Campinaranas (Santos e Nelson 1995). No Parque, as Campinaranas, semelhantes ao PARNA do Viruá (Mendonça et al. 2013), apresentam variações fitofisionômicas. À medida que a saturação hídrica do solo aumenta, formações florestais, como as Campinaranas Florestadas, são substituídas por formações de Campinaranas Arbórea e Arbustiva, seguidas pelas Gramíneo-Lenhosas, Gramíneo-Arbustivas até as Campinaranas Graminosas. A unidade revela uma extensa faixa de transição com ecossistemas florestados serranos ou de terras baixas, como Floresta de Terra Firme, Floresta de Igapó, Floresta de Várzea, Florestas Ombrófilas, Montanas e Submontanas. Além disso, em seus limites oeste, apresenta extensões variáveis de afloramentos rochosos, nos picos mais elevados, onde ocorre uma vegetação rupestre sobre substratos graníticos.

Nas últimas décadas, o PARNA Serra da Mocidade tem experimentado um processo de recuperação natural dos seus ecossistemas, após exploração extensiva pretérita com danos ambientais moderados, principalmente pelas atividades extrativistas na região (ICMBio 2018). O difícil acesso possibilitou a integridade ambiental de várias áreas do Parque, embora atividades ilegais ainda sejam frequentes, sobretudo a caça/pesca, bem como incêndios de origem antrópica.

\section{Estratificação das unidades geoambientais}

A estratificação das unidades geoambientais foi realizada a partir da análise integrada dos aspectos pedológicos, geomorfológicos e, suas respectivas fitofisionomias (Tricart e Kiewietdejonge 1992; Schaefer 1997). Além das visitas a campo, para a identificação e mapeamento dos geoambientes, foram utilizadas imagens Rapideye fornecidas pelo ICMBio. As imagens Rapideye possuem resolução espacial de $5 \mathrm{~m}$, compostas pelas bandas azul $(440-510 \mu \mathrm{m})$, verde $(520-590 \mu \mathrm{m})$, vermelho $(630-685 \mu \mathrm{m})$, red-edge 690 - $730 \mu \mathrm{m}$ e infravermelho próximo $(760-850 \mu \mathrm{m})$ (Felix et al. 2009). Dessa forma, foram identificadas, descritas e reunidas, em uma mesma terminologia, setores da paisagem com características similares em relação aos aspectos ecogeográficos avaliados.

\section{Coleta, análise e classificação dos solos}

Com base nos padrões identificados nas imagens de satélites, a partir das características gerais da paisagem, como vegetação e relevo, foram pré-classificadas as 
principais unidades geoambientais. No campo, trincheiras foram abertas em número suficiente para representar toda a diversidade de solos em cada geoambiente. Foram coletados 19 perfis de solos em fitofisionomias variadas de Campinaranas (Florestada, Arborizada, Arbustiva, Gramíneo-Lenhosa, Gramíneo-Arbustiva e Graminosa), bem como florestas (Floresta de Terra Firme, Igapó, Várzea e Ombrófila) do PARNA Serra da Mocidade. Além disso, foram utilizados os dados de solos do entorno, com ênfase no PARNA do Viruá, detalhado por Mendonça et al. (2013). Os perfis de solos foram coletados e descritos de acordo com Santos et al. (2013), até o quarto nível categórico segundo Embrapa (2013). As amostras foram secas ao ar, destorroadas e passadas em peneira de $2 \mathrm{~mm}$, para obtenção da terra fina seca ao ar (TFSA). A cor dos solos foi determinada por meio da Munsell Soil Color Charts (Munsell 1994). As análises químicas e físicas do solo foram realizadas no Laboratório de Análise de Solo da Universidade Federal de Viçosa, de acordo com Embrapa (2011). As variáveis incluíram: $\mathrm{pH}$ em água e $\mathrm{KCl} ; \mathrm{Ca}^{2+}, \mathrm{Mg}^{2+}$ e $\mathrm{Al}^{3+}$ trocáveis (extraídos com $\mathrm{KCl} 1 \mathrm{~mol} / \mathrm{L}$ ); $\mathrm{P}, \mathrm{Na}, \mathrm{K}, \mathrm{Fe}, \mathrm{Zn}, \mathrm{Mn}$ e Cu disponíveis (extraídos com Mehlich-1); acidez extraível $\left(\mathrm{H}^{+}+\mathrm{Al}^{3+}\right)$ (extraída com acetato de cálcio $1 \mathrm{~N}, \mathrm{pH}$ 7,0); Ca, Mg, Zn, Fe, Mn e Cu determinados por espectrometria de absorção atômica; e o teor de matéria orgânica $(\mathrm{MO})$, estimado pela equação: $\mathrm{MO}=$ Carbono Orgânico $\times 1,724$ - Walkley-Black. A granulometria dos solos foi obtida por dispersão com $\mathrm{NaOH} 0,1 \mathrm{~mol} / \mathrm{L}$, de acordo com o método da pipeta (Embrapa 2011). Para referenciar os solos das áreas com as maiores cotas altimétricas buscouse dados secundários do projeto Radambrasil (1975).

\section{Florística}

A fim de caracterizar cada geoambiente para além das fitofisionomias, foram coletadas as espécies com maior representatividade em relação ao número de indivíduos na paisagem.

O material botânico fértil foi tratado segundo técnicas convencionais de herborização (Mori et al. 1989) e incorporado ao herbário VIC da Universidade Federal de Viçosa (MG). A identificação taxonômica foi realizada in loco, com auxílio de especialistas e literatura especializada. O sistema de classificação utilizado foi o APG IV (2016). A nomenclatura das espécies e respectivas abreviações dos autores foram padronizadas de acordo com a Lista de Espécies da Flora do Brasil (2020).

\section{Resultados e discussão}

\section{Esboço Pedológico do PARNA Serra da Mocidade e Sequências de Solos Repre- sentativos}

O PARNA Serra da Mocidade apresenta um contraste entre serras e morrarias da zona florestada e os grandes espaços inundáveis e baixios do pediplano rio Branco-rio Negro. As porções mais elevadas da paisagem exibem um mosaico ainda 
desconhecido de Latossolos e Cambissolos, associados às formações florestais, além de pontões e afloramentos rochosos antigos, exumados pela profunda atividade erosiva por toda a borda dos sistemas montanhosos. As porções mais baixas da paisagem exibem vasta superfície aplainada e rebaixada pela podzolização extrema, num clima super-úmido, retocada por processos eólicos intensos, subatuais, sob climas secos, com, principalmente, Espodossolos associados a Campinas e Campinaranas, bem como diversos geoambientes únicos em gradientes hidropedológicos.

No parque, o significativo controle edáfico sobre as diferentes paisagens possibilitou o agrupamento dos principais solos em quatro pedoambientes descritos a seguir:

Solos das regiões montanhosas das Serras da Mocidade e Pacu

Nas áreas montanhosas ou serranas do PARNA Serra da Mocidade predominam solos profundos nas partes dissecadas em mares de morro, sempre de fertilidade natural muito baixa: Argissolos Vermelho-Amarelos, Cambissolos Háplicos e Latossolos Amarelos. São solos distróficos, derivados de rochas Granítico-Gnáissicas, e apresentam alta susceptibilidade a erosão onde a topografia é íngreme.

Acima de 1.300 m, predominam Cambissolos Húmicos ou Hísticos e Neossolos Litólicos, sempre distróficos. Os Cambissolos da região montanhosa são particularmente muito erodidos, com a formação de megafeições de movimento de massa, como cicatrizes, por toda a borda da serra. Em alguns casos os processos erosivos estão bastante acentuados com voçorocas de grandes dimensões, que podem ser vistas em imagens aéreas e de satélite.

Os Neossolos Litólicos húmicos ocorrem nas escarpas e vales mais encaixados, em relevo escarpado ou montanhoso. Possuem horizontes húmicos em função das temperaturas mais baixas e aportes de biomassa vegetal que se decompõe muito lentamente nos climas mais amenos de montanha (> $1.300 \mathrm{~m})$. Os perfis A, B e C do Radambrasil (1975) são solos representativos desse pedoambiente.

Solos sob influência de rios de Águas Brancas, Negras ou Mistas

O rio Catrimâni, no extremo sudoeste do PARNA Serra da Mocidade, apresenta formação de várzeas de natureza aluvial, argilosas, bem mais extensas e desenvolvidas que o rio Capivara. A proveniência serrana dos aluviões revela uma clara origem pedogenética para os areais que ficam na retaguarda dos mesmos, em posições altimétricas mais baixas que as várzeas atuais. Portanto, os Espodossolos dos interflúvios se encontram como que selados e rebaixados entre as várzeas Holocênicas nos rios Capivara, Univini e Catrimâni, argilosas, que impedem o fluxo hídrico normal entre os pantanais arenosos e as drenagens principais.

O rio Água Boa do Univini possui aluviões argilosos em meio a igapós e barrancas arenosas onde o rio secciona o Pantanal arenoso, especialmente em sua margem esquerda, no Niquiá. As florestas de maior porte estão associadas a esses aluviões, sem vínculo com os espaços arenizados. 
Nas várzeas holocênicas do rio Capivara (águas mistas), os sedimentos argilosos são tipicamente associados a Plintossolos Háplicos Distróficos (Suppl. material 1, Tabela S1: Perfil 15), com elevados teores de acidez e $\mathrm{Al}^{3+}$. A soma de bases é baixíssima, e os teores de $\mathrm{P}$, como regra geral em todas as várzeas do PARNA Serra da Mocidade, muito baixos $(<4,0)$. A Floresta Ombrófila Aberta, com características transicionais para Semi-Decídua, é sustentada pela ciclagem eficiente, uma vez que a CTC é muito baixa. De acordo com Chapin et al. (2002), mais de 90\% do nitrogênio e fósforo absorvidos pelas plantas vêm da ciclagem de nutrientes. Em solos com baixa CTC, a ciclagem exerce papel relevante, pois, apesar das raízes adquirirem mais rapidamente os nutrientes, a capacidade de armazenamento de cátions por unidade de volume de solo é muito baixa (Chapin et al. 2002).

Na Campinarana Florestada (Fig. 2), Gleissolos Melânicos na várzea baixa do rio Água Boa do Univiní tem lençol oscilante entre $90 \mathrm{~cm}$ de profundidade, na estação seca, até a completa inundação sazonal do período chuvoso, que dura por até 3 meses, com água até 1 metro acima do nível do solo. Horizontes húmicos superficiais denotam forte tendência ao acúmulo de matéria orgânica até $10 \mathrm{~cm}$, apesar da fertilidade natural extremamente baixa, e elevada saturação de $\mathrm{Al}^{3+}$, com valores sempre superiores a $2 \mathrm{cmol}_{\mathrm{c}} \mathrm{kg}^{-1}$ (Suppl. material 1, Tabela S1: Perfil 7). Os sedimentos têm textura argilosa a muito argilosa, e representam o domínio de áreas fontes profundamente intemperizadas à montante, com origem nas coberturas latossólicas dos divisores Ajarani/Água Boa do Univini, intensamente desgastados pela erosão. Não há qualquer reserva química nesses solos, e os teores de $\mathrm{Ca}, \mathrm{Mg}$ e $\mathrm{P}$ em nada diferem dos Espodossolos mais pobres da região.

No caso das planícies aluviais do rio Catrimâni, os Plintossolos mostram grau de evolução pedogenética maior, com desenvolvimento de caráter argilúvico e, muitas vezes, petroplíntico (Suppl. material 1, Tabela S1: Perfil 16 e 17). São solos com acidez elevada, teores de $\mathrm{Al}^{3+}$ mais baixos que outros solos de várzea dos rios Univini ou Capivara, e fertilidade natural um pouco mais elevada, mas sempre muito lixiviados e pobres. Os teores de fósforo seguem os valores baixíssimos em geral, bem como a matéria orgânica, que não mostra teores elevados no perfil. Da mesma forma, infere-se que a floresta depende de forte biociclagem, uma vez que as reservas minerais são muito baixas.

Campinaranas sobre dunas e ambientes arenosos correlatos (Sequência Igarapé Preto)

Ocorreram duas ordens de solos nas Campinaranas do PARNA Serra da Mocidade: Neossolos (Quartzarênicos) e Espodossolos (Fig. 3). Os Espodossolos acompanham a gradação de fitofisionomias e geobiótopos, à semelhança do observado para o PARNA Viruá (Mendonça et al. 2013), na outra margem do rio Branco, mas com importantes diferenças, como a presença de horizontes Bhs. As classes observadas foram: Espodossolos Ferri-Humilúvico Órtico arênico, Espodossolo Ferri-Humilúvico Hidromórfico organossólico, Espodossolo Humilúvico Hidromórfico arênico, Espodossolo $\mathrm{Hu}$ milúvico Órtico espessarênico, Espodossolo Ferrilúvico Órtico arênico, Neossolo Quartzarênico Órtico típico (Suppl. material 1, Tabela S1: Perfis 1, 3, 4, 5, 6, 10). 

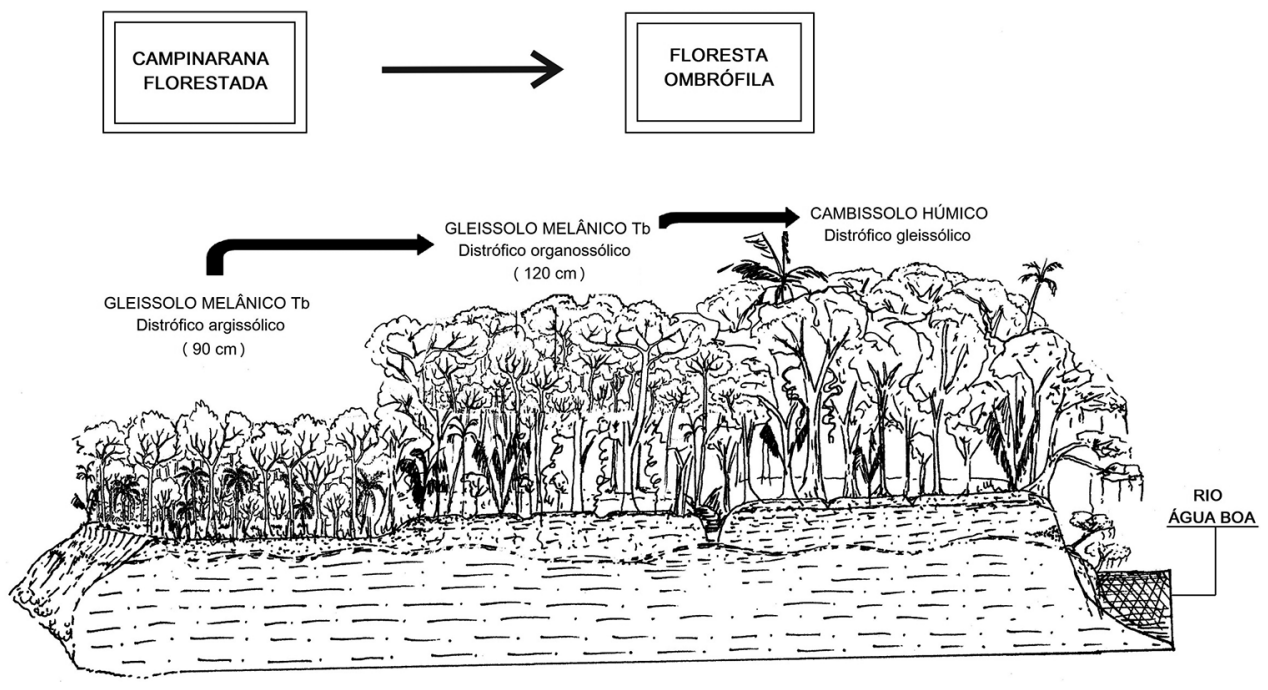

Figura 2. Paisagem representativa das formações de Campinarana Florestada sobre Gleissolos e Floresta Ombrófila Aberta sobre Cambissolos/Gleissolos do Parque Nacional Serra da Mocidade, norte do Brasil. (Ilustração: Carlos Schaefer / Edição: Hugo Galvão Candido).

\section{ESPODOSSOLO FERRI-HUMILÚVICO Órtico arênico \\ 2. ESPODOSSOLO FERRI-HUMILÚVICO Hidromórfico organossólico \\ 3. ESPODOSSOLO HUMILÚVICO Hidromórfico arênico \\ 4. ESPODOSSOLO HUMILÚVICO Órtico espessarênico \\ 5. NEOSSOLO QUARTZARÊNICO Órtico típico \\ 6. ESPODOSSOLO FERRILÚVICO Órtico arênico}

Campinaranas sobre dunas e ambientes arenosos correlatos abrangem diversos geobiótopos, cuja separação cartográfica não é possível na escala adotada. Há variações fitofisionômicas incluindo os Buritizais (comunidades dominadas pela palmeira Mauritia flexuosa L.f. (Buriti)) com Espodossolo Ferri-Humilúvico Hidromórfico organossólico, Bonnetiais (arbustais de Bonnetia sp.), Campos Arenosos Brejosos, Campinaranas Arbustivas, Campinaranas de Barcella odora (Trail) Drude, bem como Campinaranas Arborizadas, com formação de um gradiente de drenagem (Fig. 3).

Nos geobiótopos do complexo de dunas e areais, predominam Espodossolos e as seguintes fitofisionomias: Campinaranas Graminosas, Campinaranas GramíneoLenhosas de Bonnetia, Buritizais, Campinas Brejosas, Campos de Dunas, Campinaranas Arborizadas e Campinaranas Florestadas. Na direção dos topos das dunas estabilizadas, os horizontes $\mathrm{E}$ se tornam hiperespessos, e não é possível detectar o horizonte Bhs (Fig. 3).

Os teores de carbono orgânico do solo aumentam juntamente com a maior biomassa da vegetação nas Campinaranas Florestadas ou nos Buritizais. Nas fisionomias arbóreo-arbustivas o horizonte $\mathrm{E}$ álbico é mais espesso (maiores que $0,5 \mathrm{~m}$ ) e esbranquiçado, com incremento de matéria orgânica (MO) em profundidade, as- 


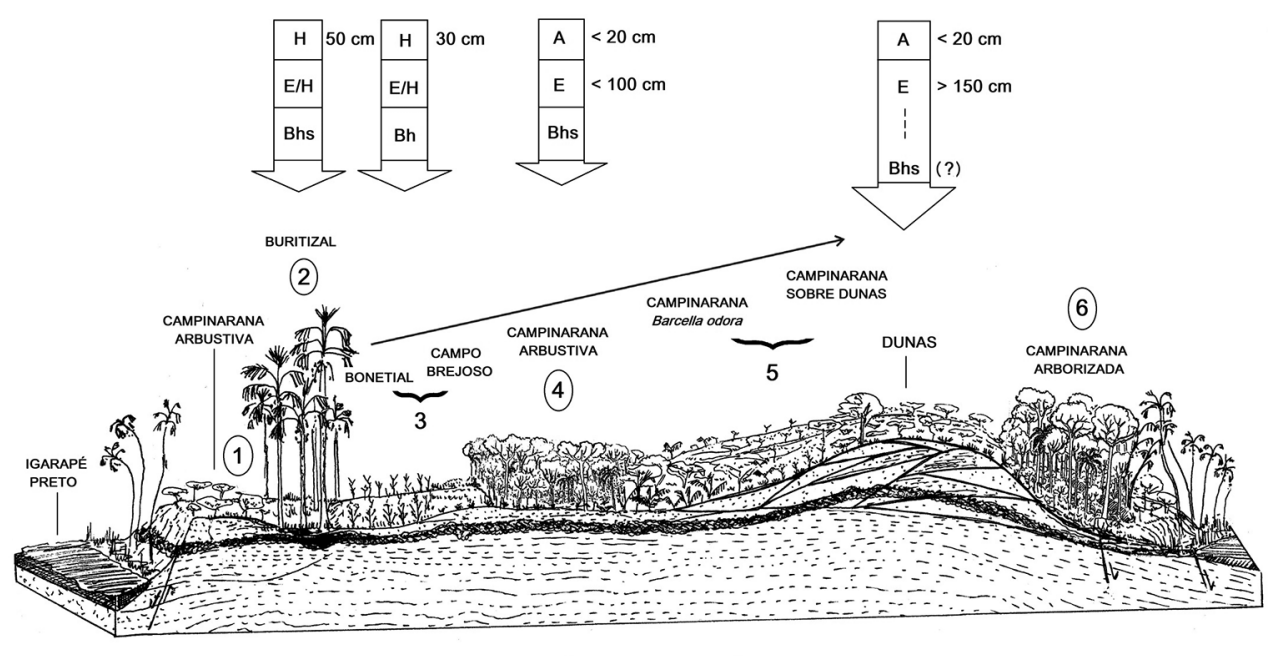

SEQUÊNCIA IGARAPÉ PRETO

Figura 3. Paisagem representativa da Sequência Igarapé Preto do Parque Nacional da Serra da Mocidade, norte do Brasil. (Ilustração: Carlos Schaefer / Edição: Hugo Galvão Candido).

sociado ou não a aumento de P-Mehlich e CTC (Suppl. material 1, Tabela S1). As diferenciações desses solos, da mesma classe, principalmente no incremento de $\mathrm{MO}$ em subsuperfície, parecem estar condicionadas à redistribuição lateral dos compostos orgânicos mobilizados, em função de variações do nível do lençol freático, com formação de microrelevos que respondem por variações florísticas da Campinarana (Fig. 3). Nas áreas mais abertas, dominadas pelas Campinaranas GramíneoLenhosas, ocorrem Campos de Dunas parabólicas fósseis (paleodunas), bem mais expressivas que no PARNA Viruá (Mendonça et al. 2013), nas áreas de interflúvio, com maior exposição aos ventos de NE. Fases mais secas de períodos glaciais promoveram sua ativação, permanecendo hoje estabilizadas e parcialmente vegetadas (Santos e Nelson 1995; Carneiro Filho et al. 2003).

A sequência de solos ao longo do gradiente Duna-Depressão Interdunas revela a dominância de materiais areno-quartzosos de fertilidade química muito baixa, com ausência de minerais facilmente intemperizáveis. No topo da duna, as areias são praticamente destituídas de nutrientes e o horizonte $C$ não possui qualquer carga negativa, com teores de matéria orgânica tão baixos que são praticamente inertes (Suppl. material 1, Tabela S1: Perfil 2). Nas Campinaranas Arbustivas (Suppl. material 1, Tabela S1: Perfis 1 e 5), os teores de P aumentam, mas a CTC é muito baixa, com $\mathrm{Al}$ trocável muito alto. São, certamente, alguns dos solos mais empobrecidos e lixiviados da Amazônia, mesmo onde a biomassa é maior, com padrão arborizado, pois o sistema areno-quartzoso não apresenta qualquer capacidade efetiva de retenção de nutrientes.

As Campinaranas sobre Dunas requerem pesquisas mais conclusivas e detalhadas. Ainda que boa parte dos depósitos arenosos tenha sido retrabalhado em con- 
dições mais secas, não há qualquer evidência de uma deposição em clima árido para justificar tão espesso manto arenoso (Schaefer et al. 2008). Não se observa seleção nem características deposicionais nesses corpos arenosos, exceto quando formam dunas bem evidentes, com ocorrência de areias bem classificadas e arredondadas, de tamanho mais fino. Abaixo destas, predominam areias residuais, não transportadas, de evidente origem in situ, por podzolização (pedogenética).

Para Mendonça et al. (2013), o que existe de concreto é a formação desses mantos como resultado de pedogênese, em condições predominantemente super-úmidas (Altemuller e Klinge 1964; Andrade et al. 1997; Bravard e Righi 1989). Não há dúvida que houve um importante retrabalhamento de suas partes superiores pelo vento, remobilizando-as, mas tais eventos foram apenas superficiais. A arenização deu-se em condições quentes e super-úmidas, e indicam a prevalência desse regime climático por boa parte do Pleistoceno terminal, alternando com fases secas, de duração variável (Fisch et al. 1998).

Nas Campinaranas Arbustivas e Arborizadas destaca-se a presença generalizada de cupinzeiros de coloração escurecida na base dos arbustos, onde, apesar da elevada acidez, os teores de fósforo e a soma de bases são maiores, como demonstraram os estudos semelhantes no PARNA Viruá (Mendonça et al. 2013). O teor de argila, CTC e MO também parecem ser superiores aos solos adjacentes. Estes resultados evidenciaram a importância dos térmitas na ciclagem de nutrientes, como apontado extensamente na literatura (Schaefer 2001; Sarcinelli et al. 2009, 2013; Mendonça et al. 2013). Nestes solos constantemente alagados e inóspitos quimicamente, os termiteiros da Campinarana, além de disponibilizarem nutrientes, permitem a boa aeração do solo e favorecem a fixação das plantas. Essas observações reforçam a estreita relação entre os térmitas e a distribuição dos arbustos na paisagem das Campinaranas.

Solos das Encostas Íngremes Florestadas e Serras baixas

Representam o ambiente pedológico típico das serras e Inselbergs, onde os Neossolos (Quartzarênicos, Regolíticos ou Litólicos) e Cambissolos predominam, sendo sempre distróficos (Fig. 4).

Nas partes rebaixadas de pé-de-serra, ocorrem saias aluviais com acumulações arenosas, associadas a Neossolos Quartzarênicos Hidromórfico típico (bem drenadas - Suppl. material 1, Tabela S1: Perfil 14) ou espodossólico (mal drenadas - Suppl. material 1, Tabela S1: Perfil 13); tais solos possuem reserva nutricional muito baixa e teores de $\mathrm{P}$ bem reduzido. Nas partes elevadas da serra, no entremeio de afloramentos rochosos graníticos, ocorrem Neossolos Regolíticos Distróficos. Esses solos indicam que, mesmo próximos da rocha, o grau de intemperismo é tão elevado a ponto da CTC ser baixa, apesar da presença de minerais primários na fração areia (Suppl. material 1, Tabela S1: Perfis 11 e 12).

As escarpas do Leste, e todo o entorno que envolve os pontões da Serra da Mocidade são associadas a solos rasos, pedregosos, onde a Floresta Aberta se estabeleceu em solos instáveis, suscetíveis à movimentos de massa em larga escala (Fig. 4). Os 


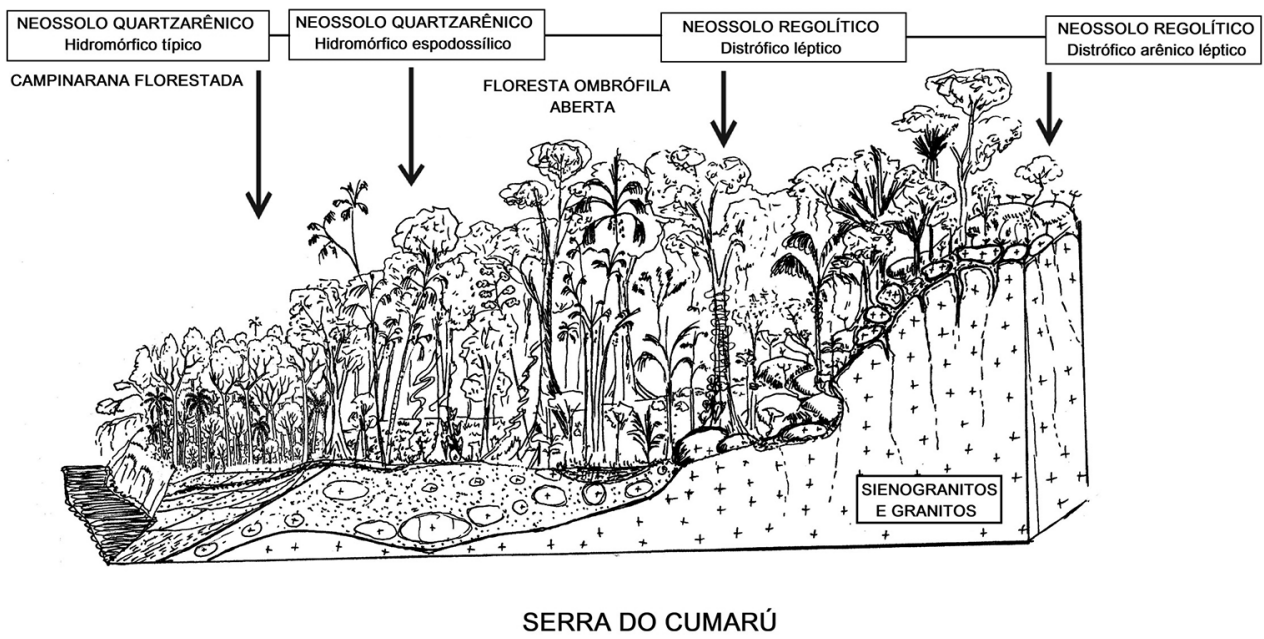

Figura 4. Esquema da paisagem representativa do rio Água Boa do Univini em direção às encostas íngremes florestadas do Parque Nacional da Serra da Mocidade, norte do Brasil. (Ilustração: Carlos Schaefer / Edição: Hugo Galvão Candido).

solos mostram padrões semelhantes aos descritos no perfil de Neossolo Regolítico Distrófico da Serra do Cumarú, ou seja, mesmo com a presença de rocha aflorante e muita rochosidade e pedregosidade, os solos não mostram eutrofia nem saturação de bases elevadas, embora os teores de P sejam mais elevados, em virtude de apresentarem muitas fraturas e fendas onde se acumulam excrementos de animais diversos.

\section{Unidades geoambientais do PARNA Serra da Mocidade}

As características pedogeomorfológicas, em conjunto com a vegetação e geologia, diferenciadas por imagens de satélites e visitas a campo, revelaram importantes traços gerais da paisagem do PARNA Serra da Mocidade. Foram identificados 12 geoambientes e diversos geobiótopos não mapeados, pela escala adotada (Fig. 1). As descrições pormenorizadas de cada geoambiente, e dos geobiótopos neles incluídos, são apresentadas a seguir e encontram-se resumidas na Tabela 1.

\section{Planícies Arenosas Inundáveis com Campinaranas Gramíneo-Lenhosas}

Esse geoambiente pode ocorrer com a presença de arbustos baixos em patamares mais densos, ou como geobiótopos de Campinarana Parque. É muito comum no PARNA Serra da Mocidade e marca o padrão aplainado inundável dos sistemas arenosos. O solo representativo desse geoambiente é o Espodossolo Humilúvico Órtico espessarênico (Suppl. material 1, Tabela S1: Perfil 5; Fig. 3). Possui uma fitofisionomia herbáceo-arbustiva, com espaçamento regular das moitas de arvoretas e arbustos, onde os solos são mais ricos em matéria orgânica e com melhor drenagem, 
fatores condicionados pela ocorrência de termiteiros escuros (dominados por cupins do gênero Nasutitermes sp. (Dudley 1890). Os termiteiros possuem um espaçamento regular, o que se aplica ao padrão de Parque e denota uma drenagem ligeiramente melhor que os solos arenosos inundáveis com vegetação herbácea de entremeio. $\mathrm{O}$ menor hidromorfismo dos solos sob termiteiros é suficiente para adensar o estrato arbóreo-arbustivo, que apresenta arvoretas, mais baixas, raquíticas e espaçadas, com dominância de Umiri (Humiria balsamifera (Aubl.) A.St.-Hil) e Clusia sp. (Apuí), além de Caraipa llanorum Cuatrec., Pagamea coriacea Spruce ex Benth., Bactris campestris Poepp. ex Mart., Platycarpum egleri G.K. Rogers, Aldina heterophylla Spruce ex Benth., Retiniphyllum sp., Byrsonima sp., Macairea sp., Ouratea sp., entre outras (Suppl. material 1, Tabela S2). No entremeio herbáceo, em condição mais inundável, dominam várias espécies da família Cyperaceae (notadamente Lagenocarpus spp.), Euriocaulaceae (Syngonanthus spp.), Poaceae, Xyridaceae (Xyris spp. e Abolboda spp.) e Melastomataceae, além da presença eventual da palmeira-anã Barcella odora nas partes mais altas das areias brancas.

\section{Complexo de Paleodunas Arenosas com Campinaranas Abertas}

Os patamares arenosos possuem uma grande complexidade de ambientes em nível local, com gradientes de formações dos campos arenosos brejosos com Campinarana Graminosa, para as planícies arenosas e paleodunas com Campinarana GramíneoArbustiva, e para as colinas e patamares arenosos altos com Campinarana Florestada (Fig. 3). Os solos representativos desse geoambiente são Espodossolo Ferri-Humilívico Órtico arênico, Espodossolo Humilúvico Hidromórfico arênico e Neossolo Quartzarênico Órtico típico (Suppl. material 1, Tabela S1: Perfis 1, 4 e 10).

Nesse geoambiente, o lençol freático é elevado o ano todo, ocorrendo Campinarana Gramíneo-Lenhosa sobre extensas planícies encharcadas, formação de áreas aplainadas e rebaixadas, de relevo deprimido e lençol freático superficial ou aflorante. O estrato herbáceo é densamente recoberto por espécies de Cyperaceae (Lagenocarpus spp.) e Poaceae. Na cobertura herbácea encontram-se ainda espécies típicas de áreas úmidas, como Xyris spp. e Abolboda spp. (Xyridaceae), Paepalanthus spp. e Syngonanthus spp. (Eriocaulaceae), Utricularia sp. (Lentibulariaceae) e Drosera sp. (Droseraceae), além de pteridófitas, como a espécie ameaçada Schizaea elegans (Vahl) Sw. (Schizaeceae) (Suppl. material 1, Tabela S2). Nas depressões onde se formam poças permanentes é comum encontrar espécies aquáticas, como Wolffia brasiliensis Wedd. e Spirodela sp. (Araceae) e Nymphaea sp. (Nymphaeaceae).

Nesse geoambiente, o lençol freático alcança nível mais superficial que o anterior, e os solos são mais lixiviados e ácidos, com maior dificuldade para o estabelecimento de árvores de maior porte. Ocorre a vegetação de Campinarana Graminosa e Arbóreo-Arbustiva, em solos com maior nível de hidromorfismo do que Planícies Arenosas Inundáveis com Campinaranas Gramíneo-Lenhosas, bem como por período mais prolongado de inundação sazonal. 


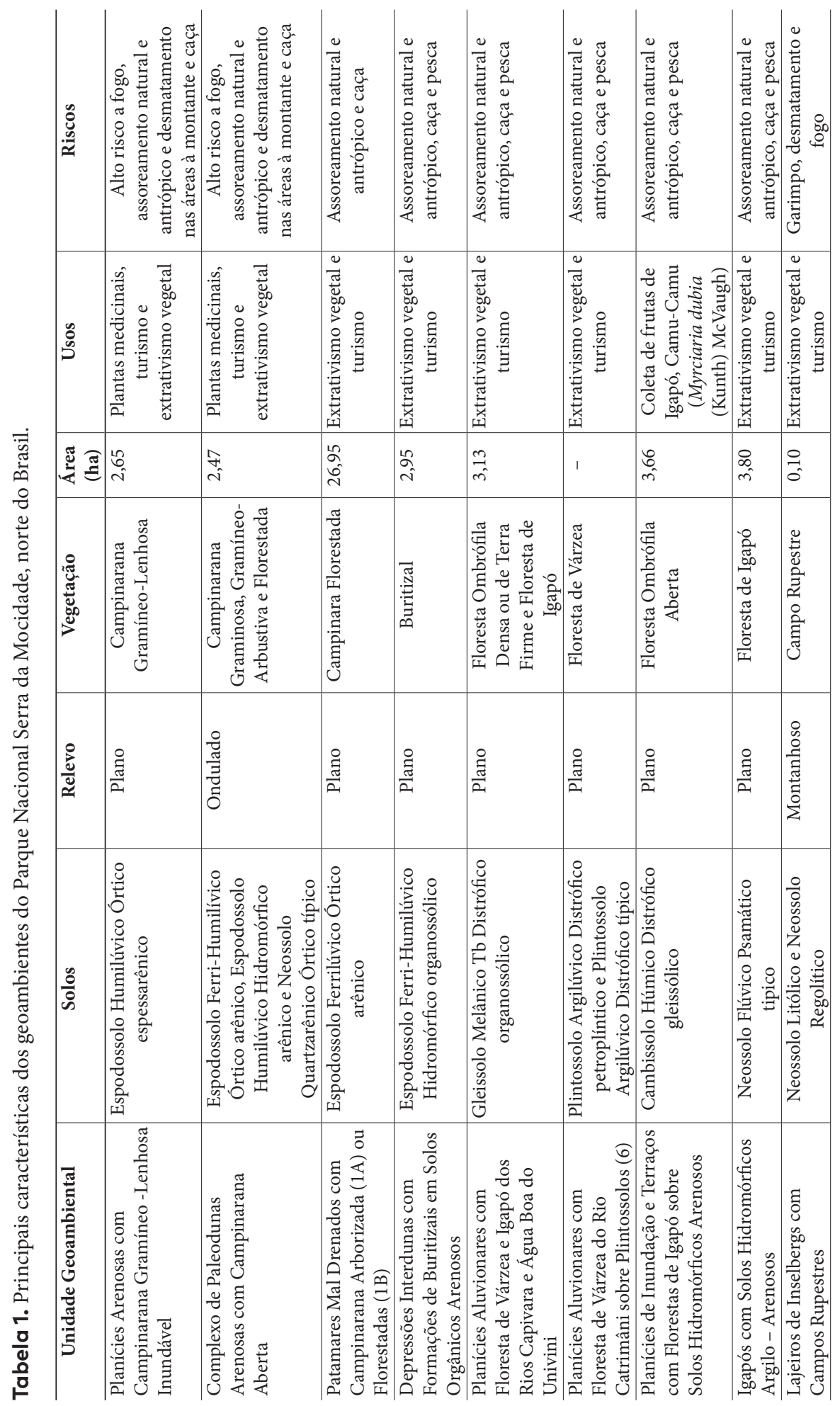




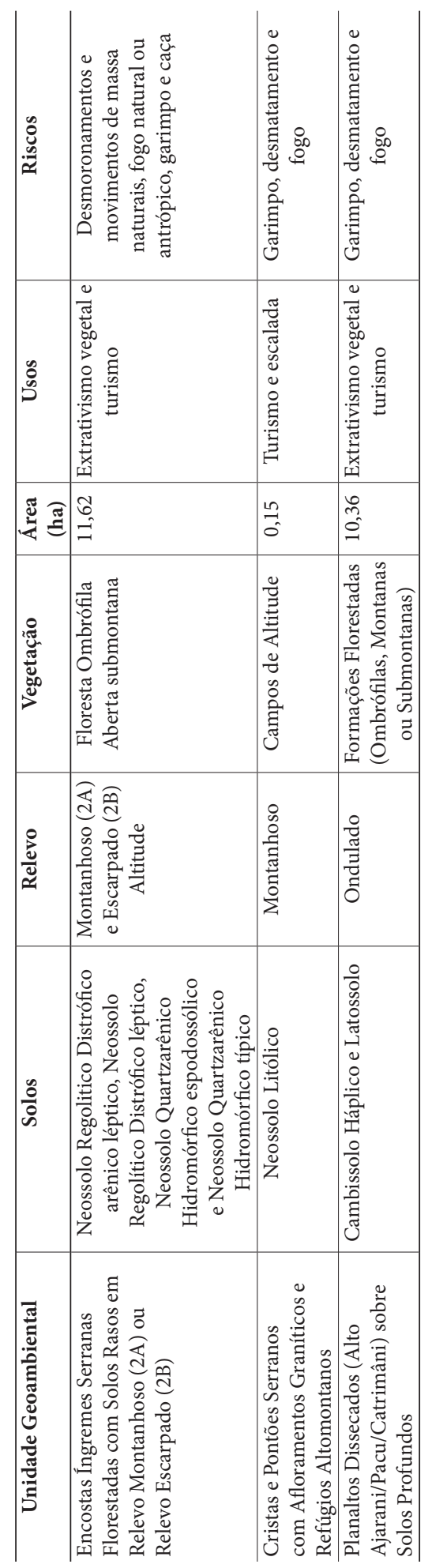


Segundo o levantamento florístico realizado no vizinho PARNA Viruá (Mendonça et al. 2013), as espécies lenhosas da Campinarana-Arbustiva arbórea também ocorrem na Campinarana Florestada, apresentando, no entanto, árvores mais baixas, raquíticas e espaçadas. As espécies Ruizterania retusa (Spruce ex Warm.) Marc.-Berti, Humiria balsamifera, Clusia sp., Caraipa llanorum parecem ser as espécies pioneiras mais comuns neste sistema sucessório. Essas espécies colonizam áreas mais abertas de Campinaranas (Campinaranas Gramíneo-Lenhosas). O menor desenvolvimento das espécies arbóreas deve-se provavelmente ao maior stress hídrico causado por lençol freático mais superficial e períodos mais longos de inundação em relação a Campinarana Florestada (Vicentini 2004). No extrato herbáceo, observase cobertura de Barcella odora, Cyperaceae, Poaceae, Xyridaceae e Melastomataceae.

O geobiótopo de Barcella odora é uma variação especial e singular dos geoambientes de Campinarana Graminosa, nas partes onde há ligeira sobrelevação do manto arenoso lavado e mal drenado. É uma das geofáceis associadas à presença conspícua de Muricis (Byrsonima sp.), Candelabro (Platycarpum egleri), Clusia panapanari (Aubl.) Choisy, além do estrato herbáceo com Cyperaceae, Poaceae, Xyridaceae (Xyris spp. e Abolboda spp.) e Euriocaulaceae (Paepalanthus spp. e Syngonathus spp.).

O geobiótopo de Depressões com Campos Brejosos e Vegetação Semiaquática sobre solos arenosos hidromórficos ocorrem onde o lençol freático é muito elevado o ano todo, mesmo no auge da estação seca, representam amplas áreas de campos inundados, e são considerados como formações pioneiras pelos critérios de Veloso et al. (1991). Os solos variam desde Espodossolos e Neossolos Quartzarênicos Hidromórficos até Organossolos. São ambientes essencialmente campestres, dominados por espécies das famílias Poaceae e Cyperaceae que suportam longos períodos de inundação. Além disso ocorrem espécies das famílias Droseraceae, Xyridaceae, Rapateaceae, Lentibulariaceae, Nympheaceae e Cabombaceae.

O geoambiente de Paleodunas abrange um megassistema eólico antigo, estabilizado, ocupando todos os principais interflúvios das baixadas do PARNA Serra da Mocidade, e representa um geossistema formado em condições áridas/semiáridas bem distintas do clima super-úmido atual. A datação desses eventos aponta para o último Máximo Glacial, quando os mesmos processos erosivos que exumaram e erodiram o manto latossólico nos divisores Catrimâni/Ajarani/Água Boa, dispararam processos de intensa remobilização de areias (pré-existentes) no Pediplano rio Branco-rio Negro, o que originou imensos sistemas de dunas, hoje praticamente estabilizados pelas Campinaranas (Schaefer 1997).

As paleodunas do PARNA Serra da Mocidade são parabólicas, simples ou compostas, com uma sequência de geobiótopos bem típica, entre a crista da Duna e as Depressões Interdunas. Indicam uma gênese vinculada a períodos de aridez no Holoceno tardio, pela facilidade de mobilização das areias sob cobertura vegetal incipiente, de Campinas Arenosas. Segundo Santos et al. (1993), representam uma parte do chamado Pantanal Setentrional, onde os processos eólicos recentes criaram corpos de areia orientados segundo os ventos dominantes (NE/SW), em direção à Planície inundável de mais de $80 \%$ da área total. 


\section{Patamares mal drenados com Campinaras Florestadas ou Arborizadas}

Representa um dos geoambientes onde as formações florestadas mais desenvolvidas respondem a sutis variações do regime de oscilação do lençol. Esse geoambiente marca o início da arenização generalizada da paisagem, e da presença de lençol freático elevado, responsável pela gênese de solos arenosos muito pobres em nutrientes, com nível de oscilação sazonal do lençol mais baixos que os demais tipos de Campinaranas. Os solos desse geoambiente corresponde ao Espodossolo Ferrilúvico Órtico arênico (Suppl. material 1, Tabela S1: Perfil 6). A vegetação associada ocorre sobre solos arenosos com drenagem um pouco melhor, desenvolvidos em sistema de patamares aplainados (pediplanados) e ocupa os relevos tabulares e arenosos mais altos, situados abaixo das encostas de colúvios argilosos, com as quais transiciona de forma abrupta. Os solos arenosos mostram acumulação de matéria orgânica em superfície e possuem sempre um horizonte húmico espesso, que sustenta a Campinarana Florestada. A Campinarana Florestada é constituída por uma floresta densa com árvores relativamente finas, com até $15 \mathrm{~m}$ de altura, de porte menor que as da Floresta Ombrófila. O solo é arenoso, com muita areia fina, profundo e rico em material humificado até $60 \mathrm{~cm}$ de profundidade. As árvores da Campinarana Florestada são de caules eretos, pouco ou nada tortuoso, e formam um dossel quase contínuo, às vezes mais aberto. As principais árvores são: Ruizterania retusa, Abarema jupunba (Willd.) Britton \& Killip, Sorveira ou Amapá Parahancornia amapa (Huber) Ducke, Andira cordata Arroyo ex R.T. Penn. \& H.C. Lima, Humiria balsamifera, Ouratea spruceana Engl., além de Aldina heterophylla, Iryanthera sp., entre outras (Suppl. material 1, Tabela 2). Segundo Gribel et al. (2008), ocorrem também espécies florestais, como a árvore emergente Sacoglottis guianensis Benth., atingindo até $20 \mathrm{~m}$, Licania heteromorpha Benth. e Caraipa llanorum, observados no PARNA Viruá (Mendonça et al. 2013).

O estrato arbustivo é denso e formado por espécies de Melastomataceae (Miconia sp. Ruiz \& Pav.) e Rubiaceae (Pagamea sp., Palicourea sp., Psychotria sp. e Retiniphyllum sp.). Ocorrem algumas espécies de palmeiras dentre as quais destacam-se as Bacabas (Oenocarpus bacaba Mart.), Euterpe catinga Wallace, Mauritiella aculeata (Kunth) Burret (Caranã ou Buritirana) e Leopoldinia piassaba Wallace. Entre as epífitas destacam-se algumas Araceae (Anthurium atropurpureum R.E. Schult. \& Maguire, Philodendron sp.) e Orchidaceae (Epidendrum sp.). Almofadas de líquens do gênero Cladonia sp. são características desse tipo de formação.

Assim como no PARNA Viruá (Mendonça et al. 2013), ocorrem geofácies de bordas das Campinaranas Florestadas com solos de transição, representando variação ecotonal das Campinaranas Florestadas em direção aos patamares arenosos mais baixos e hidromórficos, nos quais o hidromorfismo é mais forte. Caraipa llanorum predomina amplamente nessas zonas de transição com áreas de Campinaranas mais abertas, onde o lençol freático apresenta-se mais superficial do que na Campinarana Florestada. Nessas bordas, além de C. llanorum, o denso estrato arbustivo reúne comunidades heterogêneas de Ruizterania retusa, Melastomataceae (Miconia sp.) 
e Rubiaceae. Ocorrem poucas palmeiras, com destaque para Bactris campestris, Oenocarpus bacaba e Leopoldinia piassaba. Epífitas Anthurium atropurpureum e Phylodendron sp. (Araceae), além de Orchidaceae (Epidendrum sp.) são comuns.

Nas faixas de transição entre os geoambientes de Campinarana Florestada para Floresta Ombrófila ocorrem geofácies de transição entre os Espodossolos/Neossolos Quartzarênicos. Essas geofáceis correspondem a uma área de tensão ecológica, com transição florística entre Campinarana Florestada e Floresta Ombrófila Densa ou Aberta. Observa-se grande dominância de Ruizterania retusa (Vochysiaceae), típica da Campinarana, além de alta frequência de indivíduos de Parahancornia amapa, Humiria balsamifera, uma espécie de Quaruba (Vochysia sp. Aubl.), Puruí (Duroia saccifera (Schult. \& Schult.f.) K.Schum, Jacareúva (Calophyllum brasiliense Cambess.), Uxi (Licania apetala (E. Mey.) Fritsch) e Envira Preta (Guatteria discolor R.E. Fr.). Nessas faixas, observam-se muitos indivíduos mortos de Itaúba (Mezilaurus itauba (Meisn.) Taub. ex Mez), o que sugere uma mudança ambiental recente devido à elevação do lençol freático.

\section{Depressões Interdunas com Formações de Buritizais em Solos Orgânicos Arenosos}

Nesse geoambiente ocorrem solos do tipo Espodossolo Ferri-Humilúvico Hidromórfico organossólico (Suppl. material 1, Tabela S1: Perfil 3). Nos geoambientes de Formações Ripárias, dominam os Buritizais, verdadeiras Veredas de Buritis. Esses ecossistemas sazonalmente inundados com comunidades dominadas pela palmeira nativa Mauritia flexuosa e por tapete herbáceo com espécies de Poaceae e Cyperaceae ocorrem ao longo dos cursos de água (Buritizal linearizado) ou em depressões arredondadas de cabeceiras (Buritizal não-linearizado).

Em associação, também ocorrem nesse geoambiente Mauritiella aculeata, e mais raramente, Açaí-jussara (Euterpe precatoria Mart.). Nas transições com igapós, são comuns geofácies de associações de Mauritia flexuosa com Calophyllum brasiliense, Ucúba Branca (Virola sp.), arvoretas de Cybianthus sp. e Tococa sp. Nas partes mais inundáveis ocorrem campos brejosos dominados por gramíneas e ciperáceas que suportam longos períodos de inundação, como espécies de Droseraceae, Xyridaceae, Rapateaceae, Lentibulariaceae e, principalmente Nymphaea sp. (Nymphaeaceae), Cabomba sp. (Cabombaceae) e Nymphoides sp. (Menyanthaceae), além de plantas aquáticas como Wolffia brasiliensis e Spirodela sp. (Lemnaceae).

\section{Planícies Aluvionares com Floresta de Várzea e Igapó dos rios Capivara e Água Boa do Univini}

É o geoambiente de várzeas altas com terras firmes, que represa os Pantanais arenosos em sua retaguarda, com raros e episódicos pulsos de inundação mais prolongada. Representa um geoambiente de solos moderadamente a bem drenados dos Terraços Antigos dos rios Capivara e Univini com vegetação de Floresta Ombrófila Densa das terras baixas ou Floresta de Terra Firme. O solo representativo desse geo- 
ambiente é Gleissolo Melânico Tb Distrófico organossólico (Suppl. material 1, Tabela S1: Perfis 8). A vegetação é uma Floresta de Terra Firme densa com árvores de grande porte e alta diversidade florística. As palmeiras Oenocarpus bacaba, Euterpe precatoria e Inajá (Attalea maripa (Aubl.) Mart.) são particularmente abundantes. Entre as árvores destacam-se, pela frequência e porte, as espécies Licania heteromorpha Benth. var. heteromorpha, Qualea paraensis Ducke, Tachigali chrysophylla (Poepp.) Zarucchi \& Herend, Trattinnickia burserifolia Mart., Eschweilera atropetiolata S.A.Mori, Protium apiculatum Swart e Pseudolmedia laevis (Ruiz \& Pav.) J.F. Macbr (Suppl. material 1, Tabela S2).

\section{Planícies Aluvionares com Floresta de Várzea do rio Catrimâni sobre Plintossolos}

São Matas Aluviais que se desenvolvem sobre Plintossolos nas margens mais altas, sazonalmente inundáveis, do rio Catrimâni. Os solos representativos deste geoambiente são Plintossolo Argilúvico Distrófico petroplíntico e Plintossolo Argilúvico Distrófico típico (Suppl. material 1, Tabela S1: Perfis 16 e 17). Correspondem a solos com maior evolução pedogenética, desenvolvimento argilúvico e, muitas vezes, petroplíntico, pobres, muito lixiviados, com elevada acidez e baixos teores de matéria orgânica e fósforo. As Matas Aluviais são floristicamente distintas das Florestas de Várzea do rio Branco. Segundo estudos efetuados no rio Barauna (Gribel et al. 2008), onde são muito semelhantes, há predomínio de Pterocarpus rohrii Vahl, Naucleopsis caloneura (Huber) Ducke, Mouriri guianensis Aubl., Guatteria discolor, Swartzia schomburgkii var. guayanensis R.S. Cowan, Calyptranthes cuspidata Mart. ex DC., Pouteria elegans (A. DC.) Baehni, Zygia juruana (Harms) L. Rico e Heisteria laxiflora Engl.

\section{Planícies de Inundação e Terraços com Florestas de Igapó sobre Solos Hidromórficos Arenosos}

É o geoambiente florestado de maior porte, biomassa e diversidade, ocupando os terraços antigos dos rios Água Boa e Catrimâni e todos os igarapés de maior porte, que drenam a Serra da Mocidade. O lençol freático varia bem mais $(>120 \mathrm{~cm})$ do que nos demais geoambientes e a inundação aluvial é inexistente, ou muito curta. A pedogênese avançou a ponto de formar Cambissolo, com solos bem mais cromados que os Gleissolos Melânicos, associados. Na sequência mostrada na Fig. 3 observa-se um claro gradiente no sentido Floresta Ombrófila Aberta nãoinundável, Floresta Ombrófila Aberta/Campinarana na transição inundável, até Campinarana Florestada, inundável. O Perfil 9 (Suppl. material 1, Tabela S1), representativo da Floresta Ombrófila Aberta, possui fertilidade natural muito baixa, mas com teores de $\mathrm{Al}^{3+}$ menores, mas teores de $\mathrm{Ca}$ e $\mathrm{P}$ ligeiramente maiores em superfície, em função da maior ciclagem pela fitomassa florestal. Com a drenagem melhor, os teores de matéria orgânica são mais baixos, comparativamente às Florestas/Campinaranas inundáveis. 


\section{Igapós com Solos Hidromórficos Argilo-Arenosos}

São os geoambientes de extensos Igapós do rio Univini e Catrimâni, situados em níveis altimétricos das enchentes dos rios e representam uma das mais amplas áreas de Igapós do sul de Roraima. O solo representativo desse geoambiente é o Neossolo Flúvico Psamático típico (Suppl. material 1, Tabela S1: Perfil 18). O acesso é extremamente difícil, e ainda não se tem um bom detalhamento da sua composição florística. Os sobrevoos sobre o Viruá e Mocidade (Mendonça et al. 2013) indicam um porte arbóreo mais elevado, e a ocorrência de espécies como Ruizterania sp. Marc.-Berti, Clusia sp., Macrolobium acaciifolium (Benth.) Benth. (Arapari), Molongum lucidum (Kunth) Zarucchi e Buchenavia oxycarpa (Mart.) Eichler (Tanambuca).

Representa um geoambiente de amplos espaços com campos inundáveis e vegetação arbustiva com Clusia sp., Abiurana (Chrysophyllum argenteum subsp. auratum (Miq.) T.D.Penn, Molongó (Ambelania cuneata Müll.Arg.), Camu-Camu (Myrciaria dubia (Kunth) McVaugh), Licania discolor Pilg., e muitas plantas herbáceas e macrófitas aquáticas semelhantes em composição às que ocorrem nos Buritizais mais inundáveis, como Aningas (Montrichardia sp.) Philodendron sp. (Araceae), Xyridaceae, Rapateaceae, Lentibulariaceae e, principalmente Nymphaea sp. (Nymphaeaceae), Cabomba sp. (Cabombaceae), Wolffia brasiliensis e Spirodela sp. (Lemnaceae) (Suppl. material 1, Tabela S2). Ocorrem com menor frequência Buchenavia oxycarpa e palmeiras como o Jauari (Astrocaryum jauari Mart.) e uma espécie trepadeira (possivelmente Desmoncus sp.). Uma espécie da família Myrsinaceae (Cybianthus sp.) ocorre com frequência entre os arbustos observados.

Ocorrem ainda geobiótopos de Igapós Abertos com solos alagados. São ambientes de campos inundáveis com vegetação arbustiva e muitas plantas herbáceas e macrófitas aquáticas semelhantes em composição às que ocorrem nos Buritizais mais inundáveis, como Montrichardia linifera (Arruda) Schott (Aningas), Philodendron sp., Xyridaceae, Rapateaceae, Lentibulariaceae e, principalmente Nymphaea sp., Cabomba sp., Wolffia brasiliensis e Spirodela sp.

Nos Igapós, o estágio sucessional arbóreo é semelhante ao da Floresta de Igapó, com formação de extensas reentrâncias e alinhamentos de paleomeandros, com palmeiras como Astrocaryum jauari e árvores como Calophyllum brasiliense, Calycophyllum spruceanum (Benth.) K. Schum., Inga sp., Triplaris weigeltiana (Rchb.) Kuntze e Virola sp.

\section{Lajeiros de Inselbergs com Campos Rupestres}

No PARNA Serra da Mocidade, assim como no PARNA Viruá (Mendonça et al. 2013), ocorrem Campos Rupestres de Lajeiro, mas exclusivamente nos afloramentos abaixo dos 600 metros, mais quentes e secos. Correspondem a afloramentos de rochas graníticas ou alcalinas, com formação de extensos pavimentos rochosos, comuns no setor sul do Estado de Roraima. Nas Serras da Lua, Barauana e Tumucumaque, os Lajeiros formam mosaicos de afloramentos com vegetação rupestre 
xerofítica, rica em espécies das famílias Cactaceae e Bromeliaceae que não ocorrem nas florestas adjacentes. São verdadeiros refúgios de vegetação semiárida como conclaves dentro da floresta, preservados pelo clímax edáfico, com solos muito rasos ou afloramentos rochosos. Nas partes mais elevadas, são verdadeiros refúgios altomontanos bem mais úmidos, sem o mesmo padrão xerofítico.

\section{Encostas Îngremes Serranas Florestadas com Solos Rasos}

Geoambiente com ocorrência dominante de Floresta Ombrófila Aberta submontana desenvolvida sobre solos relativamente rasos, com ocorrência esparsa e frequente de afloramentos rochosos, que recobrem os setores mais íngremes e ravinados dos inselbergs e morros residuais da Serra do Cumarú e partes baixas da Serra da Mocidade e Pacu, em altitudes superiores a 80 metros.

Nas áreas de declive acentuado predominam os Neossolos (Litólicos ou Regolíticos), com a presença de blocos rochosos em superfície (Suppl. material 1, Tabela S1: Perfil 11 e 12). Nas áreas rebaixadas de pé-de-serra ocorrem acumulações arenosas, com a formação de Neossolos Quartzarênicos espodossólicos ou típicos (Suppl. material 1, Tabela S1: Perfis 13 e 14). Os Cambissolos Háplicos ocorrem nas áreas de colúvios de baixa encosta, com material grosseiro, em relevo ondulado a forte ondulado. Normalmente, estão associados a fragmentos de rocha em matacões entremeados de material fino argiloso. $\mathrm{O}$ caráter fragmentário da rocha cria boas condições de drenagem, o que permite a formação de pequenos canais de drenagem nos sopés das serras. Os Latossolos estão restritos a pequenos bolsões nas baixas encostas, com mantos de colúvios mais profundos, onde o processo erosivo foi interrompido. Além de profundos, os solos podem ser distróficos, quimicamente ácidos e de baixa fertilidade natural, resultante da influência do material de origem (profundamente pré-intemperizado).

Esse geoambiente pode apresentar solos mais profundos, quimicamente ácidos, distróficos e de baixa fertilidade natural, resultante da influência do material de origem (profundamente pré-intemperizado). Apresenta valores muito baixos de soma de bases $\left(0\right.$ a $\left.0,30 \mathrm{cmol}_{c} / \mathrm{dm}^{3}\right)$, capacidade de troca catiônica $\left(0\right.$ a $1,69 \mathrm{cmol}_{c} /$ $\mathrm{dm}^{3}$ ) e saturação de bases ( 0 a 4\%), com saturação por alumínio de $79,5 \%$ a $97 \%$ nas camadas superficiais (Parente Jr 2008).

São áreas de extrema riqueza florística, com variações faciológicas que abrangem Florestas Abertas com Bacaba, Floresta Aberta com Inajás, de Cipoais, entre outras. De acordo com Gribel et al. (2008), no PARNA Viruá, no mesmo geoambiente, as famílias mais importantes foram Lauraceae, Burseraceae, Chrysobalanaceae, Annonaceae, Moraceae e Lecythidaceae. Destacam-se as espécies: Protium apiculatum, Ocotea cinerea van der Werff, Licania heteromorpha, Licania apetala, Guatteria sp., Pseudolmedia laevis, Trattinnickia sp. e Eschweilera atropetiolata. Dentre as palmeiras, destaca-se a presença frequente de Oenocarpus bacaba (Gribel et al. 2008). No PARNA Serra da Mocidade, além dessas famílias, ocorrem elevada representatividade no número de espécies nas famílias Arecaceae, Araceae, Fabaceae e Rubiaceae (Suppl. material 1, Tabela S2). 
As espécies arbóreas de maior frequência são Protium apiculatum, Ocotea cinerea, Licania heteromorpha, Licania apetala, Guatteria sp., Pseudolmedia laevis além da presença frequente de Oenocarpus bacaba, que parece colonizar preferencialmente áreas com solos argilosos, bem drenados. Ocorrem geofácies de Floresta Aberta com palmeiras Inajá com grande abundância de palmeiras Attalea maripa em cotas um pouco mais elevadas das serras, onde ocorrem solos mais argilosos e avermelhados. A composição florestal é mais aberta e de porte elevado, diferindo pouco das formações florestais.

$\mathrm{Na}$ base das escarpas formam-se extensos tálus rochosos, que evidenciam fases semiáridas quando a erosão (morfogênese) era bem mais ativa, mobilizando grandes blocos rochosos que se acumularam nos sopés das escarpas frontais de leste. A oeste, o Planalto tem uma suave queda na direção dos formadores dos rios Catrimâni, Pacu e Ajarani, sem formar tálus.

\section{Cristas e Pontões Serranos com Afloramentos Graníticos e Refúgios Altomontanos}

Com base em fotos aéreas, identificou-se um rico mosaico de vegetação aberta, campestre, recobrindo os picos mais elevados da Serra da Mocidade, constituindo assim os únicos Campos de Altitude nebulares conhecidos nessa parte da Amazônia. O difícil acesso impediu uma inspeção dos solos, mas a vegetação parece muito semelhante àquela dos pontões do sudeste brasileiro, com dominância de espécies da família Bromeliaceae, e com uma certa afinidade à flora Tepuiana, embora especulativa. Uma expedição por solo é a única maneira de avaliar esse geoambiente singular, de enorme importância para a origem das vegetações abertas da Amazônia.

\section{Planaltos Dissecados (Alto Ajarani/Pacu/ Catrimâni) sobre Solos Profundos}

Ocorrem em forma de um planalto dissecado em mar de morros, a oeste das escarpas da serra, voltado às drenagens que formam os rios Catrimâni e Ajarani. A ocorrência de um manto de intemperismo profundo (saprolito) foi observada em diversos cortes de estrada na Perimetral Norte, no ramal que penetra no território Yanomami. À medida que o relevo se torna mais montanhoso, as rochas cristalinas gnáissicas mostram-se alteradas em grande profundidade, à exceção dos terrenos graníticos mais resistentes. Assim, o planalto dissecado em mares de morros é muito semelhante ao padrão de relevo e solos encontrados na Zona da Mata de Minas Gerais, com formações Florestadas (Ombrófilas, Montanas ou Submontanas), um tipo semelhante à Mata Atlântica. Ocorrem Cambissolos Háplicos, distróficos, nas partes mais declivosas, e Latossolos nas encostas mais estáveis e convexas. O aprofundamento do entalhe fluvial é controlado pelo manto de intemperismo profundo, mas ocorrem leitos rochosos desde os trechos mais encaixados, em rochas mais resistentes. É um geoambiente chave para o PARNA Serra da Mocidade, embora praticamente desconhecido, cuja vegetação suscita questões importantes pela similaridade com a Mata Atlântica. 


\section{Conclusões}

O PARNA Serra da Mocidade abriga um mosaico de ecossistemas, com ampla heterogeneidade ambiental e ecológica. A unidade de conservação, além de apresentar significativas áreas de Floresta Ombrófila amazônica com elevada diversidade, corresponde, em conjunto com o PARNA Viruá e Estação Ecológica de Niquiá, a uma das mais extensas e representativas áreas de Campinaranas no Brasil. Além disso, é exemplar de exceção, em meio a vastidão arenosa inundável, por representar o único conjunto montanhoso granítico-gnáissico de grande extensão e altimetricamente complexo do norte amazônico. O contraste entre as porções mais elevadas da paisagem, com um mosaico ainda desconhecido de Latossolos e Cambissolos, e os grandes espaços inundáveis e baixios do pediplano rio Branco-rio Negro, com os mais profundos Espodossolos conhecidos do Brasil, destacam as peculiaridades dos aspectos pedológicos do Parque. O significativo controle edáfico sobre as diferentes paisagens, possibilitou a descrição de distintos pedoambientes, com destaque nos solos: Espodossolo Humilúvico, Espodossolo Ferri-Humilúvico, Espodossolo Ferrilúvico, Neossolo Quartzarênico, Neossolo Regolítico, Neossolo Flúvico, Plintossolo Háplico, Plintossolo Argilúvico, Gleissolo Melânico e Cambissolo Háplico. Além dos solos, diferenças geomorfológicas, geológicas e vegetacionais foram importantes na diversidade geoambiental da unidade de conservação, com a identificação de 12 geoambientes. Dentre esses geoambientes, os que apresentaram maior representatividade em área territorial foram: Patamares Mal Drenados com Campinarana Arborizada ou Florestada, Encostas Íngremes Serranas Florestadas com Solos Rasos em Relevo Montanhoso ou Relevo Escarpado e Planaltos Dissecados (Alto Ajarani/Pacu/Catrimâni) sobre Solos Profundos. A estratificação geoambiental e suas respectivas descrições é estratégia metodológica essencial na consolidação das informações do meio biótico e abiótico, entrelaçadas, de maneira tal a auxiliar na definição mais precisa e adequada das formas de manejo e gestão do Parque.

\section{Agradecimentos}

À equipe do Parque Nacional Serra da Mocidade, especialmente Romério Briglia Ferreira e Érica Tieko Fujisaki e ao ICMBio (Roraima), pelo apoio logístico e financiamento deste trabalho; à Universidade Federal de Roraima e Universidade Federal de Viçosa, pelo apoio técnico; a Ricardo de Oliveira Perdiz (INPA- Instituto Nacional de Pesquisas da Amazônia) e demais especialistas que contribuíram para identificação das espécies vegetais; bem como aos construtivos comentários dos revisores anônimos.

\section{Referências}

Ab'Saber AN (2002) Bases para o estudo dos ecossistemas da Amazônia brasileira. Estudos Avançados 16(45): 7-30. https://doi.org/10.1590/S0103-40142002000200002 
Agência Nacional de Águas (2009) Sistemas de Informações Hidrológicas. Estação meteorológica de Caracaraí. http://www.ana.gov.br

Altemuller HJ, Klinge H (1964) Micromorphological investigation on development of podzol in Amazon basin. Plön, Max Plank Institute of Limnology. Soil Micromorphology, Amsterdam, $10 \mathrm{pp}$.

Andrade H, Schaefer CEGR, Demattí JLI, Andrade FV (1997) Pedogeomorfologia e micropedologia de uma sequência de Latossolo - Areia Quartzosa Hidromórfica sobre rochas cristalinas do Estado do Amazonas. Genomos 5(1): 55-66. https://doi.org/10.18285/ geonomos.v5i1.189

APG IV (2016) An update of the Angiosperm Phylogeny Group classification for the orders and families of flowering plants: APG IV. Botanical Journal of the Linnean Society 181(1): 1-20. https://doi.org/10.1111/boj.12385

Brandão PC, Soares VP, Simas FN, Schaefer CEGR, Souza AL, Mendonça BAF (2010) Caracterização de geoambientes da Floresta Nacional do Purus, Amazônia Ocidental: Uma contribuição ao plano de manejo. Revista Árvore 34(1): 115-126. https://doi. org/10.1590/S0100-67622010000100013

Bravard S, Righi D (1989) Geochemical differences in an Oxisol-Spodosol toposequence of Amazonia, Brazil. Geoderma 44(1): 29-42. https://doi.org/10.1016/00167061(89)90004-9

Carneiro Filho A, Tatumi SH, Yee M (2003) Dunas Fósseis na Amazônia. Ciência Hoje 191: 24-29.

Chapin FS III, Matson PA, Vitousek P (2002) Principles of terrestrial ecosystem ecology. Springer-Verlag, New York, 436 pp.

CPRM [Companhia de Pesquisa de Recursos Minerais] (2000) Programa Levantamentos Geológicos Básicos do Brasil. Projeto de Mapeamento Geológico/ Metalogenético Sistemático Caracaraí, Folhas NA.20-Z-B e NA.20-Z-D inteiras e parte das folhas NA.20-ZA, NA.20-Z-C, NA.21-Y-C e NA.21-Y-A. Estado de Roraima. Escala 1:500.000. Brasília.

Dias HCT, Fernandes Filho EI, Schaefer CEGR, Fontes LEF, Ventorim LB (2002) Geoambientes do Parque Estadual do Ibitipoca, município de Lima Duarte-MG. Revista Árvore 26(6): 777-786. https://doi.org/10.1590/S0100-67622002000600014

Dudley PH (1890) Termites on the isthmus of Panama.

Embrapa [Empresa Brasileira de Pesquisa Agropecuária] (2011) Manual de métodos de análise de solo. $2^{\mathrm{a}}$ ed. Embrapa Solos, Rio de Janeiro, $230 \mathrm{pp}$.

Embrapa [Empresa Brasileira de Pesquisa Agropecuária] (2013) Sistema brasileiro de classificação de solos. $3^{\text {a }}$ ed. Embrapa Solos, Rio de Janeiro, 353 pp.

Felix IM, Kazmierczak ML, Espindola GM (2009) Rapideye: a nova geração de satélites de observação da Terra. Anais do XIV Simpósio Brasileiro de Sensoriamento Remoto, Natal, 7619-7622.

Fisch G, Marengo JA, Nobre CA (1998) The climate of Amazonia - a review. Acta Amazonica 28(2): 101-126. https://doi.org/10.1590/1809-43921998282126

Flora do Brasil (2020) em construção. Jardim Botânico do Rio de Janeiro. http://floradobrasil.jbrj.gov.br/ 
Fonseca M, Lamas L, Kasecker T (2010) O Papel das Unidades de Conservação. Desafio da conservação 39: 18-23.

Gamba C, Ribeiro WC (2017) Conservação ambiental no Brasil: Uma revisão crítica de sua institucionalização. Revista de Estudios Brasileños 4(6): 146-160.

Giulietti AM, Raymond MH, Queiroz LP, Wanderley MGL, Van Den Berg C (2005) Biodiversity and conservation of plants in Brazil. Conservation Biology 19(3): 632-639. https://doi.org/10.1111/j.1523-1739.2005.00704.x

Gribel R, Queiróz AL, Ribeiro MGA, Oliveira FF, Palacio C (2008) Polinização e Manejo dos Polinizadores do Cupuaçu (Theobroma grandiflorum). INPA, Manaus, 32 pp.

Hawkins BA, Field R, Cornell HV, Currie DJ, Guégan J-F, Kaufman DM, Kerr JT, Mittelbach GG, Oberdorff T, O’Brien EM, Porter EE, Turner JRG (2003) Energy, water, and broadscale geographic patterns of species richness. Ecology 84(12): 3105-3117. https://doi. org/10.1890/03-8006

ICMBio (2018) Unidades de Conservação - Amazônia. Parque Nacional Serra da Mocidade. http://www.icmbio.gov.br

Joly CA, Haddad CF, Verdade LM, Oliveira MCD, Bolzani VDS, Berlinck RG (2011) Diagnóstico da pesquisa em biodiversidade no Brasil. Revista USP 89(89): 114-133. https:// doi.org/10.11606/issn.2316-9036.v0i89p114-133

Köppen W (1948) Climatologia: con un estudio de los climas de la tierra. Fondo de Cultura Económica, México, 478 pp.

Mello NGR, Artaxo P (2017) Evolução do Plano de Ação para Prevenção e Controle do Desmatamento na Amazônia Legal. Revista do Instituto de Estudos Brasileiros 66(66): 108-129. https://doi.org/10.11606/issn.2316-901x.v0i66p108-129

Mendonça BAF, Fernades Filho EI, Schaefer CEGR, Simas FNB, Vale Júnior JF, Lisboa BAR, Mendonça JGF (2013) Solos e geoambientes do Parque Nacional do Viruá e entorno, Roraima: Visão integrada da paisagem e serviço ambiental. Ciência Florestal 23(2): 427-442. https://doi.org/10.5902/198050989287

Mori LA, Silva LAM, Lisboa G, Coradin L (1989) Manual de manejo do herbário fanerogâmico. Centro de Pesquisa do Cacau, Ilhéus, 104 pp.

Munsell (1994) Soil color charts. Baltimore, Munsell Color Company, 28 pp.

Parente Jr WC (2008) Caracterização dos solos e suas relações com a vegetação natural no Parque Nacional do Viruá, norte da Amazônia. Boa Vista, RR. PhD thesis, Roraima, Brasil: Universidade Federal de Roraima.

Paz RJ, Freitas GL, Souza EA (2006) Unidades de conservação no Brasil: História e legislação. Áreas Protegidas. Editora Universitária/UFPB, João Pessoa, 243 pp.

Pitman NA, Jorgensen PM (2002) Estimating the size of the world's threatened flora. Science 298: 989. https://doi.org/10.1126/science

Radambrasil (1975) Folha NA. 20 Boa Vista e parte das Folhas NA - 21 Tumuqumaque, NB - 20 Roraima e NB - 21. Rio de Janeiro, 428 pp.

Reis NJ, Fraga LM, Faria MSG, Almeida ME (2003) Geologia do Estado de Roraima, Brasil. In: Rossi F, Lafon JM, Vasquez ML (Eds) Geology of France and Surroundins Areas. BRGM, Paris, 21-134. 
Rodrigues PMS, Schaefer CEGR, Corrêa GR, Campos PV, Neri AV (2015) Solos, relevo e vegetação determinam os geoambientes de unidade de conservação do norte de Minas Gerais, Brasil. Neotropical Biology and Conservation 10(1): 31-42. https://doi. org/10.4013/nbc.2015.101.05

Santos JOS, Nelson BW (1995) Os campos de dunas do Pantanal Setentrional. Congresso Latino Americano. Temário 4. Caracas, Venezuela, 9 pp.

Santos JOS, Nelson BW, Giovannini CA (1993) Corpos de areia sob leitos abandonados de grandes rios. Ciência Hoje 16(93): 22-25.

Santos HG, Jacomine PKT, Anjos LHC, Oliveira VA, Lumbreras JF, Coelho MR, Almeida JA, Cunha TJF, Oliveira JB (2013) Sistema Brasileiro de Classificação de Solos. $3^{\text {a }}$ ed Embrapa. Brasília, 353 pp.

Santos T, Filho V, Rocha V, Menezes J (2017) Os impactos do desmatamento e queimadas de origem antrópica sobre o clima da amazônia brasileira: Um estudo de revisão. Revista Geográfica Acadêmica 11(2): 157-181.

Sarcinelli TS, Schaefer CEGR, Lynch LS, Arato HD, Viana JHM, Albuquerque Filho MR, Gonçalves TT (2009) Chemical, physical and micromorphological properties of termite mounds and adjacent soils along a toposequence in Zona da Mata, Minas Gerais State, Brazil. Catena 76(2): 107-113. https://doi.org/10.1016/j.catena.2008.10.001

Sarcinelli TS, Schaefer CEGR, Fernandes Filho EI, Mafia RG, Neri AV (2013) Soil modification by termites in a sandy-soil vegetation in the Brazilian Atlantic rain forest. Journal of Tropical Ecology 29(5): 439-448. https://doi.org/10.1017/S0266467413000497

Schaefer CEGR (1997) Ecogeography and human scenario in northeast Roraima, Brazil. Ciência e Cultura 49(4): 241-252.

Schaefer CEGR (2001) Brazilian latosols and their B horizon microstructure as long-term biotic constructs. Australian Journal of Soil Research 39(5): 909-926. https://doi. org/10.1071/SR00093

Schaefer CEGR, Michel RFM, Chagas CS, Fernandes Filho EI, Valente EL, Souza E, Vasconcelos BNF, Ribeiro ASS (2008) Relatório do levantamento pedológico, geomorfológico e geológico para o Plano de Manejo do Parque Nacional da Serra do Cipó e APA Morro da Pedreira. Viçosa: UFV/DPS.

Tricart J, Kiewietdejonge C (1992) Ecogeography and rural management: a contribution to the international geospherebiosphere program. Longman Scientific \& Technical, Harlowl, $267 \mathrm{pp}$.

Veloso HP, Rangel Filho ALR, Alves Lima JC (1991) Classificação da Vegetação Brasileira, adaptada a um Sistema Universal, IBGE. Rio de Janeiro, 124 pp.

Vicentini A (2004) A vegetação ao longo de um gradiente edáfico no Parque Nacional do Jaú. In: Borges SH, Iwanaga S, Durigan CC, Pinheiro MR (Eds) Janelas para a biodiversidade no Parque Nacional do Jaú: uma estratégia para o estudo da biodiversidade na Amazônia. Fundação Vitória Amazônica, WWF, IBAMA, Manaus, 117-143. 


\section{Supplemetary material 1}

Características químicas e físicas dos solos do Parque Nacional Serra da Mocidade Authors: Carlos Ernesto Gonçalves Reynaud Schaefer, Prímula Viana Campos, Hugo Galvão Candido, Guilherme Resende Corrêa, Raiza Moniz Faria, José Frutuoso do Vale Jr

Explanation note: Tabela S1. Características químicas e físicas dos solos do Parque Nacional Serra da Mocidade, norte do Brasil. Tabela S2. Lista florística das espécies amostradas no Parque Nacional Serra da Mocidade, norte do Brasil, apresentada em ordem alfabética de famílias, gêneros e espécies.

Copyright notice: This dataset is made available under the Open Database License (http://opendatacommons.org/licenses/odbl/1.0/). The Open Database License $(\mathrm{ODbL})$ is a license agreement intended to allow users to freely share, modify, and use this Dataset while maintaining this same freedom for others, provided that the original source and author(s) are credited.

Link: https://doi.org/10.3897/neotropical.15.e49221.suppl1 